\title{
Potentials and Sustainability Index of Small-Scale Sports Tourism in Batu City
}

\author{
Indhar Wahyu Wira Harjo ${ }^{1}$, Anik Susanti ${ }^{1}$ \\ ${ }^{1}$ Department of Sociology, Brawijaya University, Indonesia \\ Correspondence: Indhar Wahyu Wira Harjo, Department of Sociology, Brawijaya University, Indonesia.
}

Received: December 1, 2017

Accepted: January 2, $2018 \quad$ Available online: January 5, 2018

doi:10.11114/ijsss.v6i2.2828

URL: https://doi.org/10.11114/ijsss.v6i2.2828

\begin{abstract}
The present study aims at investigating the menaces towards tourism sustainability in Kota Wisata Batu (KWB - Batu city as an icon of tourism). The menaces took place due to the hotel constructions in the city that experienced an increase over the last four years. However, the resorts enlargement was not in line with the increasing number of visitors in the city. In addition to the issue of physical constructions, the city also suffered from natural environment and social matters along with the growth of tourism activities. Agropolitan-based tourism has not so far been able to sustain the balance of economic, environmental, and social demands, so it is necessary to design alternative attempts to maintain the tourism activities in KWB. The model of tourism in small scale with a basis of sports is believed to be able to handle the aforementioned problems. Small-scale sports tourism is potential to overcome the demands of social welfare as well as to protect the environment during tourism activities. Thus, the present study aims at conducting an observation on the potentials of small-scale sports tourism in KWB and performing assessment on the sustainability of the sports tourism. The study carried out mixed method of research with inductive theoretical direction. The results of the study indicate that the potential of small-scale sports tourism is present at tourist destinations that explore natural resources, cultures, and something artificial. The sustainability index gained from the study is 29.81154 that is still under the category of less sustainable. The condition is due to the low assessment of economic, social, and environmental aspects of sustainability. Therefore, there should be alteration in the management of small-scale sports tourism in Batu city in order to make the natural, cultural and artificial tourism destinations economic-, social-,and cultural-friendly.
\end{abstract}

Keywords: sustainable tourism, tourists, economic welfare, social welfare, environmental protection

\section{Introduction}

Tourism will potentially suffer from involution if it ignores the aspect of sustainability. The issue on sustainability of income source and environment damage will keep existing as caused by the tourism orientation on short-term profits. Sustainable tourism management has been trusted as one of the solutions to deal with such tourism drawback (Hassan, 2000 , p. 239; Liu, 2003, p. 460). The model of sustainable tourism is highly needed to reduce the negative risks of tourism activities towards the nature and the local people's life around the tourism sites.

The development of sustainable tourism needs to be implemented in Kota Wisata Batu (KWB - Batu city as the icon of tourism), East Java Province due to the fact that in the last four years, there has been an increase of the number of hotels built. In 2012, there were 473 hotels, and in the following year the number kept increasing along with the opening of three new hotels. The increase of the hotel establishment remained exist in 2014 and 2015 with 500 and 550 buildings respectively (Central Bureau of Statistics of Batu City, 2016c, p. 19). However, the increasing number of the hotels is not in line with the improved number of visitors in each of the hotels.

The available hotel rooms experienced an uplift in 2012-2015 alongside the hotels establishment in KWB. Nevertheless, the number of visitors staying in all the hotels even suffered a fall in the same period of time. The rooms rose from 5.092 in 2013 to 5.484 in 2014 and reached its peak at 6.066 in 2015. Meanwhile, the visitors staying in hotels around KWB that was recorded as many as 1.165.104 in 2013 dropped to 666.945 in 2014, and even lower to 514.089 in 2015 (Central Bureau of Statistics of Batu City, 2016b, p. 22, 2016c, p. 19). Thus, the development of hotels building that was once projected to enhance the capacity of tourists in KWB ended up with disappointment.

Based on the data above, the number of tourists staying in KWB was not in line with the availability of tourism accommodation facilities. The extension of hotel facilities is in fact not a determinant in increasing the number of guests 
staying in the resorts. Building hotel has even triggered a conflict in the surrounding community, as happened in the case of the construction of Rayja Hotel in Bulukerto Village, Bumiaji District. The construction of the hotel had actually received permission from the local government but had to stop because it was rejected by the local residents, academics, and environmental activists. The rejection of the construction is due to the inn's potential to threaten the preservation of the nearby Gemulo springs (Harjo \& Farobi, 2016, p.474). The construction of hotels in KWB shows a less environmentally oriented model of tourism development. Therefore, the sustainable management of tourism in KWB should be carefully planned.

There is a need to design a sustainable tourism planning that contributes to reducing problems in managing tourism in KWB. Since declaring itself as a city of tourism in 2010, the development of tourism in the region has been growing rapidly. The development of KWB as a tourist destination has attracted the attention of investors from outside the city. The investors flock to invest for tourism development by building a number of new tourist artificial destinations. However, in the end, the artificial tourist attractions built by the investors actually cause environmental problems (Attar, Hakim, \& Yanuwiadi, 2013, p.68).

The man-made attractions in KWB reflect to the model of tourism targetting large-scale visitors which contribute the largest to the regional income (PAD) in the city (Attar et al., 2013, p.69). Up to August 2017, tourism had contributed 9.8 billion rupiahs or 72 percent of PAD of the city ("Wisatawan Membeludak, Karaoke Sepi", 2017). The figure shows a special contribution from the tourism sector to Batu City government's financial revenue.

Despite its great contribution to city's financial revenue, tourism that invites many visitors also raises a number of issues that need to be addressed. The mass tourism spawned problems related to traffic congestion, garbage accumulation and other pollution (Nurhidayati, 2015, p.4; "Wisatawan Membludak, Karaoke Sepi", 2017). The presented issues urged the stakeholders to find solutions to avoid the impact on the decline in the number of tourists visiting KWB.

The above issues have become the focus of the city government's attention to be addressed immediately. The concrete attempt to solve the problem is by making changes to the strategy of tourism development that was originally based on mass tourism destinations into nature-oriented tourism. The strategy is actualized in the Local Regulation of Batu City No. 7 of 2011 on Spatial Plan of Batu City 2010-2030. As an agropolitan-based city and a leading tourism city in East Java (Batu City Government, 2011), the spatial arrangement of KWB, as said in Article 5 of Local Regulation, should be safe, productive, and sustainable. The establishment of tourism villages around the administrative regions of KWB is an example of the efforts to synergize tourism and agriculture activities. As a result, there were 12 tourism villages developed on the basis of agricultural activity in 2015 (Nurhidayati, 2015, p.4).

The existence of tourism villages have, in fact, not been able to be a powerful solution to overcome the problems of tourism in KWB. At least until 2011, the implementation of agropolitan had not shown significant results. The implementation within that time span has not been able to balance the demands of the economic, social, and environmental sectors (Rozikin, 2012, p. 240). The de velopment of agropolitan-based tourism indeed indicates the potential of sustainability in the economic aspect, but in the contexts of ecology, social, and infrastructure, it is still less sustainable (Rahayu, Bambang, \& Hardiman, 2013, p.33). Thus, it is necessary to observe some alternatives of tourism management in KWB that are potential to perform sustainable tourism model.

A viable alternative for today's sustainable tourism models is sports-based tourism destinations. Small-scale sports tourism can be an option to develop such sustainable tourism. It is compatible with the principles of sustainable tourism in the sense that it is able to contribute to the sustainability of economic, social and environmental pillars in tourist are as (Gibson, Kaplanidou \& Kang, 2012, p.169). Higham (1999) stated that attending small-scale sport matches could bring positive impact for the host community. It is due to the fact that the matches usually held by adjusting to the available infrastuctures, that they only require investment from public fund, that they are easily manageable in terms of crowd and traffic, and that they are able to minimize the seasonal effects. Thus, small-scale sports tourism is expected to cope with the problems of tourism in KWB.

KWB has a set of potentials that fit the concept of developing small-scale sports tourism. Small-scale sports tourism refers to the events attracting more participants than the audience, involving limited national media coverage and limited economic activities (Gibson et al., 2012, p.169). The orientation of such tourism model is not only financial gain, but also its balance with social and environmental aspects. There have been plenty implementations of managing sport-based sustainable tourism through a wide range of sport types in various countries. Papua New Guinea, for instance, has been successful in designing sustainable tourism with major commodity of surfing. The local government performs a key role in making sport-based sustainable tourism a sustainable source of profit for the host area (O'Brien \& Ponting, 2013, p. 170). Similarly, Grande Cache Canada has offerred ultramarathon (Canadian Death Race) as one of tourist attractions with concern on small-scale sporting event (Hinch \& Holt, 2016, p. 2). Malaysia is also able to 
organize the similar type of tourism in Kenyir Lake by holding the main activity of mountain biking and motorcrossing (Yusof, Omar-Fauzee, Shah, \& Geok, 2009, p. 49). Those examples of best practice can be a stimulus to administer sustainable tourism with the basis on small-scale sports event in KWB. Tourist destinations in KWB that are relevant to these characteristics include outbound tours, rafting sites, and motocross circuits. The attractions of such tourism activity need to be well managed in order to shape a sustainable asset of tourism in KWB.

Tourist destinations in KWB supporting sports tourism are sustained by the geographical structure of the region in the form of mountains. The geographical contours of the highlands have a great appeal to sports activities. Sports activities, such as outbound, ideal to perform in locations, such as Agro Kusuma, Selekta, Songgoriti, and Coban Rais. Sports challenging adrenaline such as tubing and rafting can also be done along Brantas River of the city. Even offroad sports fans will find their interest in a number of KWB areas such as the Jalibar Circuit or Klemuk hills in Songgoriti. In addition, KWB possesses other potentials that uphold sports tourism namely paragliding, horse-riding, and swimming.

The management of sustainable sports-based tourism with a wide variety of sports has been implemented in a number of countries. Papua New Guinea, for example, has managed to design sustainable tourism with the main commodities of surfing sports. Local government plays an important role to make sports-based tourism a source of sustainable profit for the host (O'Brien \& Ponting, 2013, p. 170). Another similar example is Canada's Grande Cache which performed ultramarathon sports (Canadian Death Race) as an attraction for managing sustainable tourism with small-scale sporting event models (Hinch \& Holt, 2016, p.2). Malaysia also successfully managed this kind of tourism model in Kenyir Lake with the main activities of mountain bike and motocross (Yusof, Omar-Fauzee, Shah, \& Geok, 2009, p.49). A number of those best practices can be used as a stimulus to manage sustainable tourism that is based on small-scale sports in KWB.

Based on the aforementioned discussion, this study aims at investigating the potential of sports-based tourism in KWB as an initial effort to design a sustainable tourism model. The research is necessary with regards to the importance of sustainable tourism development to meet the needs of tourists, tourism businesses, host communities, and environmental protection (Liu, 2003, p 467). Therefore, a serious study of the potential of sports-based tourism in KWB is urgent to encourage the better of managing sustainable tourism.

\section{Method}

This research used qualitative and quantitative mixed research methods with inductive theoretical directions. The theoretical direction is oriented to the discovery of theory rather than testing theory. The design was chosen with a view to developing descriptions and exploring the meaning and interpretation of the phenomenon. Furthermore, the type of design used in the study refers to the multi-method design "KUAL+kuan". This type combines both quantitative and qualitative research methods simultaneously (Morse, 2010, pp. 177-179).

Qualitative research method was implemented to identify and conduct a description of the potential of small-scale sports-based tourism in KWB. Furthermore, to elaborate the description, this research used quantitative research method. Quantitative research methods was used to measure the sustainability index of the tourism destinations with the pilot project in Oro-Oro Ombo Village, Batu Sub-District. The village was chosen with the consideration that the region is experiencing rapid de velopment of tourism. Furthermore, there is also a massive change in the livelihoods of its citizens from the agricultural sector into tourism (Al-fath, 2016, p.74). Therefore, the study of the sustainability of small-scale sports-based tourism in this village will provide important information related to tourism management in KWB.

\section{Qualitative Research Design}

Qualitative method in this research aims to describe the potential of small-scale sport-based tourism in KWB. This description is used to provide a detailed overview of the situation and social settings of the small-scale sport-based tourism in the city. This research used interview, observation, and documentation techniques as data collection strategy. The technique of determining informants was done in purposive means, with the criteria of selected informants that have the characteristics of sampling of context and sampling of participants (Bryman, 2012, p.417). Sampling of context is intended as the criterion of informants who live around sports-based tourism destinations. Furthermore, sampling of participants is an informant who is involved in the management of tourist destinations and visitors of sports-based tourism in KWB.

\section{Quantitative Research Design}

Quantitative research method was used to measure the index of sustainability small-scale sports tourism in KWB. The size of the index is useful for demonstrating the potential of small-scale sport-based travel destinations to maintain a balance between economic, environmental, and social demands. The technique of data collection is survey to measure the index of sustainability of small-scale sport-based tourism in the city. This data collection technique used closed questions using the Likert scale. This scale is used because it has advantages that can differentiate levels within a group (Kusmayadi \& Sugiarto, 2000, p. 94). So that the use of this scale can be used to design a small-scale sports-based 
tourism sustainability index in KWB.

The population in this research is the community of Oro-oro Ombo village, Batu sub-district. The population of this village was considered fit the study due to their ownership of a lot of sports-based tourist locations that are quite close to each other, namely Mega Star Horse Farm, Motor Cross, and Outbond. The population of this study is 2.891 KK (Central Bureau of Statistics of Batu City, 2016a, p 21). Based on that number of population, the proportional sample using Slovin formula of 97 samples were determined.

The data analysis technique from the result of quantitative survey was processed using Rapfish (Rapid Assesment Techniques for Fisheries) software which is modified into Rap-S3 (small-scale sports tourism). Analytical products from these tools generated a number of small-scale sports-based tourism sustainability index in Oro-Oro Ombo village. Further data were analyzed using standard procedure of reduction, display, and data analysis.

\section{Tourism Development Plan of Batu City}

Tourism development in Batu city is designed continuously within a certain period of time. The tourism development plan is set forth in the regulation on Spatial Planning and Regional Planning (RTRW) in 2015-2030. The regulation provides guidance for the development of the tourism sector that is part of the city's overall development. Thus, the development of tourism in the city can not be separated from the development plan of Batu city.

The development design of Batu City as stated in the RTRW 2010-2030, contains guidance in strategic area planning of tourism sector. The strategic area plan for the development of tourist areas in relation to the economic sector is directed to three main activities, namely: Community Life Journey, Adventure and Nature Tour, and City Tour. These three activities become a forum for various tourism activities held in Batu city until the year of 2030.

The tourism type of Community Life Journey is presented into activities under the management of Tourism Village. Tourism village, according to the RTRW 2010-2030 regulation, refers to the form of integration between attractions, accommodation and supporting facilities presented in a community life structure that blends with the prevailing procedures and traditions (Regional Development Planning Board of Batu City, 2011, pp. V- 2). The tourism village located in Batu is categorized into two main concepts of accommodation and attractions.

The tourism village which has the main concept as accommodation will provide some local residences as temporary resort for tourists visiting Batu city. While the concept of attraction-based tourism village includes all the daily life of the local population along with the physical setting of the village location that allows the tourists to integrate as active participants. Tourist attractions within this frame are intended for the natural, cultural and man-made creations that are interesting from the village.

The two concepts that became the benchmark of the development of Community Life Journey were developed for the achievement of specific goals. The designed activities of village tour aim at observing the pattern of the local community's life and participate in all community activities in the agricultural sector of apples, oranges, and ornamental plants. The actualization of the plan is represented in the form of Garden Homestay and Agro Tourism.

Garden Homestay, in the development of tourist plans in Batu city, is directed to the villages that have agricultural potentials. Garden Homestay is mainly embodied in the bunya village tour in the Sidomulyo village, Punten village, Gunungsari village, and Tulungrejo village. The main concept used as a tourist commodity is the activity of living with flowers farmers. Tourist attractions of the activity presents a natural landscape colored by the beauty of the flowers. In addition, tourists can also participate in observing, planting and picking ornamental plants such as Flower Gladiolus, Rose, Chrysanthemum, and Anthurium.

In addition to Garden Homestay, Agro Tourism is also a mainstay of Community Life Journey tourism program. Agro Tourism in Batu city is centered in Bumiaji village, Oro-Oro Ombo village, and Tlekung village. The main commodities of horticulture crops in these locations are apples and oranges. Tourist attractions that are served in Agro Tourism activities include observing, planting, and picking apples and oranges.

The second tourism development plan is Adventure Tour and Nature Tour. These tourism categories aim to facilitate tourists who will do adventure in the open space. The adventure activities are directed to four main site plans:

1. The tourist enhancement of golf and rest area in Torongrejo village, Junrejo sub-district

2. Paragliding activities and off road circuits in Gunung Banyak

3. Camping Ground at Cangar hot spring.

4. Hanging trains, resorts, and cottages.

The next tourism development plan is City Tour that includes tourism activities to enjoy the beauty of the city. The development of attractions in this plan encompasses enjoying thematic buildings, such as the ancient buildings of the 
Dutch relics along Jalan Panglima Sudirman and pedestarian ways.

The last tourism development plan is Shopping and Culinary Tour. This tour is supported with food and be verage variants that become the attractions of Batu city. In addition, the development of tourism in this category also includes the development of recreational parks, such as Jatim Park, Batu Night Spectacular, and the world's miniature of monumental buildings, animal museums, and other means of tourism infrastructures.

\section{Potentials of Sports-Based Tourism Destinations in Batu City}

Leisure activities on a small-scale sports basis can be made at various tourist destinations in Batu city. Almost every tourist attraction in the city offers the potential for small-scale sporting events. Here are small scale sports-based tourism destinations spread across several districts in Batu city:

Table 1. Sports-Based Tourism Destinations in Batu City

\begin{tabular}{ll}
\hline Destinations & District \\
\hline Hiking & Bumiaji and Batu \\
Kaliwatu Rafting & Bumiaji \\
Gunung Banyak Paragliding & Batu \\
Mountain bikes (Downhill) & Batu \\
Circuit Cross of Oro-oro Ombo & Batu \\
Megastar Horse Ranch & Batu \\
\hline
\end{tabular}

Hiking or mountain climbing activities are a popular sporting option for young people. Sports on foot but with uphill field is the choice of young people to spend their leisure time or to do their hobby. Hiking as a positive activity has a lot of advantages, one of which is to shape a healthy body and usually accompanied with the goal of nature conservation. In Batu city, hiking activities can be done in several natural tourist points including Mount Arjuno and Mount Welirang, Mount Panderman, Gunung Banyak, Coban Talun, and Coban Rais. Hiking is done while enjoying the beauty of the scenery and the cool fresh air, so this sport is actually beneficial for body fitness and psychological health.

Sports activity that can be done in the mountain area is paragliding that belongs to extreme sports. Paragliding is actually a professional sport but it will be a fun entertainment for the audience who watch this. In Batu city, paragliding is also one sport that is promoted as a tourist destination. This paragliding location is in Gunung Banyak that has become tourists' attention due to its charm of scenery. Paragliding as a tourist attraction in Gunung Banyak usually allow tourists who want to try to do this extreme sport by paying a sum of money ranging from Rp $350,000-\operatorname{Rp} 600,000$ depending on the package selected by the tourists. For the first time, tourists attempting to try this sport will be accompanied by an instructor or tandem who has experienced in this paragliding sport. The facilities provided by this paragliding sport include beverages and snacks, taking photographs during paragliding, paragliding posters or postcards, stickers, and pins, as well as a shuttle that accommodates the travelers from the paragliding headquarters. Each facility can be selected by travelers based on the package provided by the paragliding sports manager.

Paragliding sport activities make use of mountain ridges, parachutes, strong winds and strong body to succeed the flying. Paragliding activities also rely on the weather and the physical strength of the pilots, otherwise they will encounter risks during flying. Sports tours that can be visited in addition to paragliding in Gunung Banyak is mountain bike that is usually done just under the hills of Gunung Banyak, local people call it Klemuk, in the village of Songgoriti, in the district of Batu. Mountain bike sports activities employing bikes that are specially designed to be able to pass the mountain area. Mountain bike itself is divided into several classes of XC (Cross Country), Trail, AM All Mountain, Free Ride, and Downhill.

Downhill has become one of the most frequent sports competitions held in Batu city. This sporting competition becomes a regular momentum every year, and Klemuk hill is awarded as the steepest hill that is known to have high levels of difficulty to conquer. This momentum has brought in domestic and foreign athletes to join competition eve ry year. This event is sponsored by private parties to provide entertainment for tourists. Downhill is an extreme sport that can only be done by the trained or experienced people or athletes.

Similar to other extreme sports that use a bike with a challenging track field to conquer, motor cross has turned into a much loved sport. Unlike the downhill sports that really use the physical power to pedal a bicycle, motor cross relies on both physical and mind fitness to beat the challenge. This sport is similar with do wnhill in a way that not all people can do it unless they are the professional and experienced ones because these extreme sports require mastery of skills and riders dexterity. Motor cross requires the dexterity of the riders, focused mind to pass the track that is usually made of a steep ground, and physical endurance to cope with the fast speed of the ride. The motor cross arena is available at the Jalibar Circuit of Batu city, Dresel village, Oro-Oro Ombo Batu Batu.

Close to the motor cross arena, there is also a horse ranch that has become a sports arena. Megastar Horse Farm is located in Dresel village, Oro-Oro Ombo Junrejo of Batu city. This horse ranch is managed by PT. Megastar in 
collaboration with Perhutani and Batu city government which aims to implement silvopasture program from Perhutani. Megastar Horse Ranch also has a racetrack, while the riding itself is considered as a recreational, art, culture as well as sports activity. Horses are one of the animals that can be utilized by human power. Howe ver, there are skills that must be mastered when riding a horse. Horse riding has become one of the sports that attract attention from the middle-upper class society since the activity is believed to gain their prestige since it costs a lot of money to take care of everything, including the horse care.

To enter this horse ranch area, tourists are charged $\mathrm{Rp}$ 25.000. In the ranch, there are two available race tracks where usually tourists enjoy watching the performance of the horses and horse jockeys. Horse riding also requires skills that must be mastered and not everyone can do it. Therefore, tourists who are interested to do horseback riding should pay Rp 50,000 to be able to do the ride under the supervision of experienced guide. Tourists who are not able to ride a horse can enjoy the entertainment of the horse actions while appreciating the breathtaking landscape of Mount Panderman and take pictures among the blooming sunflowers.

Batu city also often promotes water sports that can be enjoyed by tourists, such as rafting. This rafting service is spread in three districts in Batu city, namely Kaliwatu Rafting in Bumiaji District, Batu Rafting is in Batu District, and Sahabat Air in Junrejo District. All three take the same route of swifting along Brantas River from different starting points. Rafting is very popular among all ages because it provides a fun experience involving tense situation, challenging routes, and team cooperation. This branch of sports trained people to have courage to challenge the swift flow of Brantas River.

Rafting is not only a sports, but also as a means of tourism that gives the interesting impression of adventure for the tourists. Rafting in Batu city has gained a place in the hearts of the local people and tourists outside of the city. This sport activity combines the stunning beauty of the city and the crashing heartbeat of visitors on an inflatable boat on the river. Batu city is also planning to develop other sports facilities in Forest Park located at Jalan Sultan Agung Batu sub-district. Bondas Forest Park was established in 2011 has been functioned as the forest of the city.

Bondas Forest Park is a green open space that is functioned as an arena and means for gathering that is decorated with beautiful trees and plants. Bondas forest is often used as a jogging track by the people of the city. Sport facilities are still in the process of development, such as the construction of wall climbing. The construction of wall climbing facility has never existed before in Batu, so it is expected that this sport facility development can fulfill people's interest, especially those who like this kind of sport. The construction of wall climbing is targeted to be completed by the end of 2017 and become one of icons of Batu tourism city.

\section{Sustainability Index of Small-Scale Sports Tourism}

Potentials of sports tourism in Batu city are spread in various locations. Tourist destinations with a base of natural richness, artificial tourism, and cultural tourism have the capacity to hold small-scale sports events. In this study, the potential in Oro-Oro Ombo village has been measured for its sustainability based on economic, social, and environmental aspects. The results of the measurement of the sustainability of tourist destinations in the location can be observed in the following table:

Table 2. Sustainability Index of Small-Scale Sports Tourism in Oro-oro OmboVillage

\begin{tabular}{ccc}
\hline Aspects measured & Index & Category \\
\hline Environment & 28.77125 & Less sustainable \\
Economy & 29.94084 & Less sustainable \\
Social & 29.94084 & Less sustainable \\
Recapitulation & 29.81154 & Less sustainable \\
\hline
\end{tabular}

The sustainability of sports tourism activities in Oro-Oro Ombo village is closely linked to the tourist attraction. The following will be described in sequence the attractions of each of the small-scale sport attractions of Outbond in Coban Rais, the Megastar horse ranch and Motor Cross. Outbond in Coban Rais and the Megastar horse ranch are in a forest area owned by Perhutani. The existence of sports-based tourism that existed since the last 10 years is managed by forest village community institutions ( $\mathrm{LMDH}$ ) in cooperation with investors. The cooperation took place under the supervision of the Oro-Oro Ombo village government. The presence of a relatively new tourist destination raises various responses both from the community and from the village administrators.

The existence of tourism in Oro-Oro Ombo village brings an impact on people's lives, especially in Dusun Dresel, Batu District, Batu City. Previously, the tourist area that stands today was used by the public to find cattle animal's feed. Despite the compensation from the coordination among village administrators, LMDH, and Perhutani, the community is the one who felt the most positive and negative impacts. The presence of Coban Rais attractions, Megastar Horse Ranch and Motor Cross can be beneficial to the community or even harm the local community. The most visible harm is how the position of society is disturbed by the presence of tourist attractions as disclosed by Mr. Supriyono as the head of 
general affairs, Oro-Oro Ombo village.

'the problem is that the local people here also have a land, so it is all about the family matter, my grandfather has a land named Kolonjono. The land grows grasses, for feeding the cows. Now with the existence of tourist attractions, the land has become less. That's the subject of the debate" (12 August 2017)

Knowing what is felt by the people of Dusun Dresel, the village administrators, Perhutani, and LMDH provide the best way for the common good. One step taken is to provide jobs in one of the tourist destinations located in the Oro-Oro Ombo village Batu. Working opportunities are available in the forms of opening stalls or shops without paying rent, but there is a charge for the cost of cleanliness every month, and the tax is decided by Perhutani of Rp 500 per meter. The tourism attractions in Oro-Oro Ombo Village is the natural charm of forest in the mountains and the existing Coban Rais waterfall. Also, the uniqueness of this natural charm is equipped with the adding facilities of playgrounds, sports sites, and photo spots. Other supporting facilities are camping grounds, outbound activities, mushala, rest area and toilet.

Meanwhile, in order to facilitate the needs of visitors on food and resorts, the local people of Dusun Dresel offer a lot of food stalls and local places to stay. The attraction of the place is also added by providing some good spots to take pictures that for most people are instagramable. Tourists that have experienced in visiting Coban Rais and Megastar horse ranch can post fancy photos for the purpose of their social media. From the postings, there will be wider network that know the existence of the place and will someday find a time to drop by.

The network manager Coban Rais realizes that social media containing self-portraits of visitors has great tendency to attract tourists. Therefore, the manager of Coban Rais tourist attraction adds facilities that allow tourists to take photos at a swing with altitude, flower garden, board view, dad I Love U, love boards and tree swings. Unfortunately, the addition of the facility does not accommodate visitors from all age segments, such as toddlers and elderly. Playground facilities are seen less secured by some visitors because they look too shabby. In addition, the lack of directions and ranges of distance between one vehicle to another one are also not adequate, so they makes visitor feel uncertain. Visitors who bring babies feel the need for the availability of strollers and the paved roads. It is a challenge that needs to be addressed wisely, so in the future Coban Rais keeps growing any better.

Meanwhile, the attractiveness of the motor cross targets the fans of motor cross sport throughout Malang Raya and surrounding areas. Incidentally, the village head has a crooked land area between 2-3 hectares located in the hills. The crooked land is then utilized by the motor cross community, as agreed by the village head, in Dusun Dresel to build the circuit and organize some events. Furthermore, the managers do some kinds of promotion through pamphlets and billboards about the existence of motor cross events in Oro-Oro Ombo village. The selection of locations that are also far from the settlement aims to anticipate the emergence of air and sound pollution that can disrupt the peace of the people especially during the dry season. There are two challenges for the existence of motor cross attraction, namely the village head's permission on the use of the crooked land for the circuit and also the intensity of or ganizing the events.

In addition to considering the attraction of tourist destinations, the managers also need to analyze and map the needs of tourists. The results of the needs analysis are the basis for providing satisfactory services, so that travelers will be motivated to come back in the future. For example, the Megastar horse ranch plans to add several rides in the form of flowers other than sunflowers, archery while riding, making a tourist icon with sunflowers and open a horse-riding school. The steady and relatively increasing visits by the tourists are one factor that supports the sustainability of small-scale sports tourism.

\section{Sustainability Index of Economic Aspect}

The development of tourism objects contributes to the surrounding community, especially the diversification of businesses that lead to increased revenue. Likewise, the sustainability of small-scale sports tourism in Oro-Oro Ombo village is also closely related to its contribution to the economic activities of local people. Based on the measurements that have been made, the index value in the economic aspect is 28.77125 , the figure shows that sports-based tourism destinations located in Oro-Oro Ombo village is in the category less sustainable. The following description describes the conditions leading to the lack of continuing small-scale sports tourism in the village.

Changes in the variety of jobs have started in the Oro-Oro Ombo village since Coban Rais and the Megastar horse ranch operated. Prior to the Megastar horse ranch, most people worked as farmers and cattle ranchers. Coban Rais tourism object recruited most residents around as workers. Meanwhile, the Megastar horse ranch also recruited approximately twenty workers from various locations. Although there are workers who come from the city of Situbondo and Mojokerto, but most workers are recruited from Dusun Dresel. These workers occupy various positions ranging from grass-seekers, horse nurses, plant nurses, cashiers and management employees. Some of the local residents who are able to capture business opportunities provide lodging services, motorcycle taxi, and food stalls.

There are around 40 stalls lined up between Megastar and Motor Cross tourist areas. The land is a crooked land given as 
the salary of the village head. Once there is a horse ranch tour, the land is rented out to residents at a cost of Rp 500,000 per year. Enterprises established with food trade aims to increase household income, and so many other residents follow the business by opening some stalls. The owners of these stalls further form a community of merchants around the tourist area. Each trader is charged Rp 10,000 for the payment of cleaning services.

Revenue earned by opening a stall is greater than the income when being a rancher and farm laborer. When working as a farm laborer, they earned a salary of Rp 60,000 per day. At the time of raising, they must wait for the proceeds of the sale of cattle within a few months. This momentum is used to earn more money by being a taxibike riders for example, the income earned up to Rp 100,000 or even more. Planning of starred hotel construction around the sights is also considered by seeing the enthusiasm of people who came to Oro-Oro Ombo village. Employing local people should be well designed, otherwise it might trigger future problems along with the existence of the tourist destinations. Let's say, a row of hotels that are not accompanied by an increase in the number of guests who stay will affect the existence of the food traders to open their stalls at a certain time only, and the presence of motorcycle taxis will be less beneficial because many of them are unemployed.

Other opportunities related to the improvement of the economy of the residents is the presence of street vendors who are around the tourist attractions, but are seasonal or only found at certain times if the destinations are full of visitors, such as during Idul Fitri and New Year. There is a canteen in Megastar horse ranch that is opened by the residents with free of charge rent. When there are a lot of visitors drop by at the sites, the cafeteria owner rewards some sort of rent to the manager voluntarily. Basically, the management of Megastar horse ranch is a cooperation between LMDH and Perhutani, so there are a lot of varieties of crops planted in the area which is owned by Perhutani, but they are managed directly by the residents. The people who manage the tourist destination is preferably the young people who need the job, so that there are implications on the reduction of unemployment in Dusun Dre sel, Oro-Oro Ombo village, Batu city.

Regarding the close distance between Coban Rais and Megastar Horse Ranch within one area, the available work space is spread among the surrounding tourists destinations, including the Motor Cross tours. Of the three sports-based tourism in Oro-Oro Ombo village, Coban Rais tour is the most absorbing workforce because it has the most attractions requiring a lot more of labors as compared to the other two. Megastar Horse Ranch only absorbs a few number of labors because it require people with special skills. The manpower available at the Megastar ranch is a shadow economy sector, such as the presence of street vendors, tour guides, and lodging. The ownership status of the ranch is individual, and the owner is an investor who is native Malang. The management and ownership of the Megastar Horse Ranch contributes to the increasing purchasing power of tourists that benefits the local people of Dusun Dresel.

Unlike the Megastar horse ranch, the existence of Motor Cross tours since 2014 is less certain in creating job opportunities. Employment opportunities take place when there is a certain event so that it requires coordination between the local residents and the organizers of motor cross community. Outside of the event, on Saturdays and Sundays, the circuit is used for training so it is quite crowded. Jobs that are open from the event include jobs as parking attendants, street vendors and fuel sellers. The existence of such traders brings them financial benefits.

There is a symbiotic-mutualism relationship here, the fuel and food sellers gain financial profits and the motor cross riders are thankful since they do not need to go far away from the circuit to fulfill their needs. The management system of joining local residents is directly related to the policy of Oro-Oro Ombo village. So far, the village has provided facilities and supports for the existence of tourism which has an impact on the economic improvement of citizens with a note on certain events while erratic motocross events are held. Economically the existence of motor cross do not only bring benefits to local residents, the closed unemployment is also still a problem in Dusun Hamlet eventhought it is not clearly seen.

The existence of a number of tourist destinations has a sustainability index that is in a less sustainable category. Based on the above explanation, the condition happens because the open job opportunities offered by the sector are limited. Recruitment of employees, street vendors and services available at tourist sites are limited in number and time. This is the main trigger causing the tourist destination that has less sustainable contribution of economic sector for local communities.

\section{Sustainability Index of Social Aspect}

The changes of economic aspect were also in line with the changes of social aspect including the interpersonal relations among the local residents, social institutions, social dynamics, pattern of work division, social mobility, power distribution, increasing social deviations, and cultural and traditional existence in society. The sustainability of small-scale sports tourism is closely related to its contribution to society's living. According to the conducted measurement, the index shows 29.94084 that is categorized into less sustainable.

The local residents of Oro-Oro Ombo can feel that their environment has now been busier by the existence of tourism 
activities. Social interaction with people from other cities has actually affected the locals' lifestyle, especially the habit to take care of the cleanliness to look good in front of the visitors. The shifting role of women from a housewife into a breadwinner has now been identified. Before the emergence of tourism destination of Coban Rais in the area, they only performed domestic role. Currently, some housewives have already participated in making a living by opening a food stall. Despite the increased number of tourism activities, the sense of kinship and togetherness of the village community is maintained well. The regular Quran recitation activities are still conducted by the residents. In fact, the increasing activity of tourism has inspireed the residents to develop local arts. Karawitan groups formed by local residents are often invited to perform at Coban Rais. The existence of social deviation is not visible any longer.

The tourist destinations in Oro-Oro Ombo village have brought a change for the locals, one of which was the shift to more diverse occupations. The occupational changes performed by the local residents do not change their condition to vertical rise or do not make any changes towards their social aspect. They only make a shift profession that serves as a momentary opportunity by local residents because the profits look tempting. The tourist destination in Dusun Dresel, Oro-Oro Ombo village has not been properly managed yet and still requires renovation. The most visible and leading to the conflict is the seizure of parking lots for tourists among the locals, and the arrangement of street vendors.

"Yeah, the problems are probably about the seizure of parking lots and the selling foods" (result of the interview with Bapak Wiwit).

Socialization as a transitional society has not been prepared for the residents in Oro-Oro Ombo village, especially they who are directly adjacent to tourist attractions. Society needs to adapt to the outside matters that will be accepted by them. Coordination on three sports-based tourism and community readiness are not merely oriented to economic aspect, but also to social and environmental aspects.

The three sport-based tourism destinations with a small scale in this location are often visited by teenagers. Based on the observation, there will automatically be the effects towards social behavior of local communities, especially teenagers. In Oro-Oro Ombo village, there are many inns or homestays owned by the residents. Their private homes are built in such a way to attract tourists to visit and stay. The influence is not immediately apparent, but it gradually erode the values of harmony of Batu city residents.

Motor Cross activity has brought positive aspects, especially for young people who use their spare time to exercise. Motor users in these sports activities also are also affected in their way of thinking, that is the absence of tolerance to drive among users of the highway. The attractiveness of motor cross also gives influence on youth associations not to be in touch with drugs and to pay a lot more love to automotive world. However, this kind of activity also does not guarantee that their social environment will stay positive. It did not rule out the existence of wild racing that utilizes the Jalibar area in the city.

The motor cross members do not only consist of young men, but also teenage girls. The wild motor cross racing activity is followed by teenage girls whose dressing manner is adopted from Western cultures. For them, there is a demand to follow the fashion trend as a cheerleader in the wild racing arena. Adopting a culture from foreign countries can come from anywhere without filtering, for example from the most visible social media. This is in line with Mr. Suparman's remark about the changing lives of the local people as follows:

"For example, in the past there was not any activity like this. From day to afternoon, they only dressed as simple as possible, but now when the day comes they have taken a bath and dressed up. Because they want to be a center of attention among the tourists" (the result of interview with Bapak Suparman, August 2017).

The influence of social media has become one indication of how the local people make changes for themselves. Some of them imitate what tourists usually do and they also imitate from social media of the way to dress, talk, and make gestures. Tourists visiting Coban Rais get information from social media to finally be able to get a feel for the photo spots as Coban Rais's main attraction. Based on the observation, the location of this tour is more often visited by teenagers and adults. Moreover, the photo spots and the tourists who took photos by showing the romance between two lovebirds are inappropriate since they are seen by children, for example the way they take photo in 'I Love You' spot. This spot is always a target for coupled travelers, although it can be used as a family spot but this spot affects the development of children's way of thinking when they are not provided with insight and knowledge that can be accepted by children's logic. Two tourist destinations in Oro-Oro Ombo are less friendly for underage children, let alone for toddlers.

\section{Sustainabi lity Index of Environment Aspect}

The de velopment of tourism area in Oro-Oro Ombo village turns out to have an impact on the physical environment. Tourism sustainability from environmental aspects is closely linked to the maintenance of the city's beauty and the handling of problems in ecosystems, such as garbage and forest destruction. Measurements made in this aspect show a 
sustainability index of 28.77125 , that means it is under a less sustainable category.

The city government realizes that tourism activities can provide disturbances on cleanliness issues. Therefore, the government has a Sapta Pesona program that is socialized to the residents in order to have safe, clean, beautiful, cool, friendly, orderly and memorable tourist destinations. Furthermore, the Sapta Pesona program is devised to determine an adequate tourist destination as an ecotourism. Meanwhile, the people of Oro-Oro Ombo know that tourism activity also has the potential to pollute the environment.

The presence of tourists from various parts of the city must be problematic, especially related to waste caused by tourists. Trash is no longer something that is not valuable to the local residents, it is used by the local residents to recycle and finally make some money. As said by Mr. Usman:

"we pay a resident here that is appointed to be responsible as the waste administrator. LMDH pays the salary for that person's work. The waste is then classified into liquid and solid waste. But LMDH only employ some locals for taking care of the waste regarding the wide open space of forest." (12 August 2017)

Villagers in Dusun Dresel, Oro-Oro Ombo village are not equipped with waste management methods, but the efforts of separating between organic and inorganic waste have been helpful in the recycling waste. The responsibility of environmental hygiene is not only burdened to tourists who often carelessly throw the waste in some corners of tourism spots. The waste accumulation in the tourist area that sells the aesthetics of forests is the responsibility of Perhutani by employing local people by sharing income.

Street vendors are considered as the originator of the garbage problem, so that every merchant is charged Rp. $10,000.00$. For forest destruction, Perhutani has carried out reforestation by planting pine trees. Some people feel lucky because there is a change in the forest aesthetics in Coban Rais that has become much more interesting. No less important to the Sapta Pesona program, the garbage bank program in KWB also plays a role in handling the hygiene issues. The local people are aware of the benefits that are gained through their involvement in the waste bank program. The waste banks make the environment clean and make people aware of the importance of cleanliness. The banks are also able to process waste into goods which has economic value. People can also deposit the waste in exchange for money.

In the outbound tourism object, the waste management has not provided an economic value because the officers only collect and transport the waste to the landfill. The locals feel that there is nothing to be concerned about the existence of sports-based tourism in Oro-Oro Ombo village. This is supported by the narrative of Mr. Usman as a breeder who usually looks for elephant grass to feed his livestock:

"The environmental issue has so far been fine. I don't really know much about the anticipation programs for handling the environment sustainability, but I can say they are good. As far as I know, there has been some changing management. "(the result of interview with Bapak Usman Sakti Al Basori in 16 August 2017).

So far people have not felt any significant changes to the environmental conditions around them. They only feel that their environment still looks beautiful and neat. Even if they are at disadvantage, for example due the density of the vehicle, they will not complain anything. The existence of tourist attractions, such as Coban Rais, Megastar Horse Ranch, and Motor Cross are regarded as progress by locals.

The community has so far never been disturbed by the presence of tourism in Oro-Oro Ombo village. Various developments are greeted with gratitude by them because their village has gained some popularity through the existing potentials of the village. For the breeders, the most important thing is that they can still provide food for livestock, and for other residents they can still benefit through the economic income by trading, motorbike taxi, guardian of tourist attractions, or become a parking attendant.

\section{Conclusion}

Batu city has a varied tourism potentials ranging from natural-based tourist destinations, cultural tourism, and artificial tourist attractions. The entire tourist attractions are potentially developed with a small-scale sports-based tourism model. This small-scale sports can be held in natural, cultural, and artificial tourism destinations. The combination of top down and bottom up policy plannings is intended for the tourism programs launched by the Batu city's government to be synchronized with the needs and aspirations of the community. So, they can actively participate in making use of and promoting tourism sectors, especially sports tourism that is based on small-scale. The sustainability of small-scale sports tourism of the economic aspect is determined by its contribution to the city government's and local residents' revenues. The sustainability of small-scale sports tourism of environmental aspect is related to the maintenance and conservation of the physical environment. Meanwhile, the sustainability of small-scale sports tourism of social aspects is related to the interpersonal relationships among community members, social institutions, the dynamics of social life, the pattern of division of labor, social mobility, power distribution, improvement in social deviations, and the existence of culture and customs of society. 


\section{References}

Al-fath, E. D. (2016). Dari Menanam Buah menjadi Menanam Rumah: Transformasi Sosial Ekonomi Masyarakat Kota Batu. Journal of Indonesian Tourism and Policy Studies, 1(2).

Attar, M., Hakim, L., \& Yanuwiadi, B. (2013). Analisis Potensi dan Arahan Strategi Kebijakan Pengembangan Desa Ekowisata di Kecamatan Bumiaji Kota Batu. Journal of Indonesian Tourism and Development Studies, 1(2), 68-78.

Badan Pusat Statistik Kota Batu. (2016a). Statistik Daerah Kecamatan Batu 2016. Batu.

Badan Pusat Statistik Kota Batu. (2016b). Statistik Daerah Kota Batu 2016. Batu.

Badan Pusat Statistik Kota Batu. (2016c). Statistik Perhotelan Kota Batu. Batu.

Bryman, A. (2012). Social Research Methods (4th ed.). New York: Oxford University Press.

Gibson, H. J., Kaplanidou, K., \& Kang, S. J. (2012). Small-scale event sport tourism: Acase study in sustainable tourism. Sport Management Review, 15(2), 160-170. https://doi.org/10.1016/j.smr.2011.08.013

Harjo, I. W. W., \& Farobi, Y. E. C. (2016). Konstelasi Media Massa Lokal dalam Gerakan Penolakan Pembangunan Hotel Rayja. In Jendrius, E. Susanti, I. Ruwaida, B. Haryono, Herlan, \& Azwar (Eds.), Prosiding Konferensi Nasional Sosiologi V. Padang: Laboratorium Sosiologi FISIP Universitas Andalas.

Hassan, S. (2000). Determinants of market competitiveness in an environmentally sustainable tourism industry. Journal of Travel Research, 38(February 2000), 239-245. https://doi.org/10.1177/004728750003800305

Higham, J. (1999). Sport as an Avenue of Tourism Development: An Analysis of the Positive and Negative Impacts of Sport Tourism. Current Issues in Tourism, 2(1), 82-90. https://doi.org/10.1080/13683509908667845

Hinch, T., \& Holt, N. L. (2016). Sustaining places and participatory sport tourism events. Journal of Sustainable Tourism, 9582(November). https://doi.org/10.1080/09669582.2016.1253703

Kusmayadi, \& Sugiarto, E. (2000). Metodologi Penelitian dalam Bidang Kepariwisataan. Jakarta: Gramedia Pustaka Utama.

Liu, Z. (2003). Journal of Sustainable Sustainable Tourism Development : A Critique Sustainable Tourism Development : A Critique. Journal of Sustainable Tourism, 11(11), 459-475. https://doi.org/10.1080/09669582.2011.580586

Morse, J. M. (2010). Prinsip-prinsip Metode Campuran dan Rancangan Penelitian Multimetode. In A. Tashakkori \& C. Teddlie (Eds.), Handbook of Mixed Methods in Social \& Behavioral Research (pp. 170-187). Yogyakarta: Pustaka Pelajar.

Nurhidayati, S. E. (2015). Studi evaluasi penerapan Community Based Tourism (CBT) sebagai pendukung agrowisata berkelanjutan. Masyarakat, Kebudayaan Dan Politik, 28(1), 1-10. https://doi.org/10.20473/mkp.V28I12015.1-11

O’Brien, D., \& Ponting, J. (2013). Sustainable Surf Tourism: A Community Centered Approach in Papua New Guinea. Journal of Sport Management, 27(2), 158-172. https://doi.org/10.1123/jsm.27.2.158

Pemerintah Kota Batu. (2011). Peraturan Daerah Kota Batu Nomor 7 Tahun 2011 tentang Rencana Tata Ruang Wilayah Kota Batu Tahun 2010-2030. Batu: Pemerintah Kota Batu.

Rahayu, A., Bambang, A. N., \& Hardiman, G. (2013). Strategi Peningkatan Status Keberlanjutan Kota Batu Sebagai Kawasan Agropolitan. Jurnal Ekosains, V(1), 21-34.

Rozikin, M. (2012). Analisis Pelaksanaan Pembangunan Berkelanjutan di Kota Batu. Jurnal Review Politik, O2(02), 219-243.

Wisawan Membeludak, Karaoke Sepi. (2017). Radar Batu, p. 5.

Yusof, A., Omar-Fauzee, M. S., Shah, P. M., \& Geok, S. K. (2009). Exploring small-scale sport event tourism in Malaysia. Research Journal of International Studies, 9(9), 47-58.

\section{Copyrights}

Copyright for this article is retained by the author(s), with first publication rights granted to the journal.

This is an open-access article distributed under the terms and conditions of the Creative Commons Attribution license which permits unrestricted use, distribution, and reproduction in any medium, provided the original work is properly cited. 